\title{
Phosphorus, carbon and nitrogen enrichment during sedimentation in a seasonally anoxic lake (Lake Lugano, Switzerland)
}

\author{
Mauro L. Veronesi*, Alberto Barbieri and Kurt W. Hanselmann ${ }^{1)}$ \\ Ufficio Protezione e Depurazione Acque, Sezione Protezione Aria, Acqua e Suolo, Dipartimento del Territorio, Riva Paradiso 15, \\ 6900 Paradiso-Lugano, Switzerland \\ ${ }^{1)}$ Institute of Plant Biology/Microbiology, University of Zürich, Zollikerstr. 107, 8008 Zürich, Switzerland \\ *e-mail corresponding author: mauro.veronesi@ti.ch
}

\begin{abstract}
Sedimentation fluxes of major nutrients are investigated during 1996 and 1997 at three different depths and two locations in eutrophic southern basin of Lake Lugano (Switzerland). Horizontal differences between the two sites are on the order of 10-40\% (but can exceed 50\%), whereas differences related to interannual oscillations range between 5 and 24\%. Particulate organic carbon (POC) and nitrogen (PN) fluxes show a constant increase of 5-20\% from the upper to the bottom trap. This tendency remains more or less constant during the year. On the contrary, particulate phosphorus (PP) shows a seasonal variation, with higher accumulation rates from the I to the III trap in autumn and winter which can exceed $+1200 \%$. This phenomenon is due to the interaction between the dissolved phosphorus $(\mathrm{DP})$ and the iron(oxi)hydroxides $\left(\mathrm{Fe}(\mathrm{OH})_{3}\right)$ near the oxycline. $\mathrm{Fe}(\mathrm{OH})_{3}$ precipitates at the iron redox boundary, scavenging DP. This enrichment flux increases together with the development of the anoxic benthic layer. The efficiency of the iron redox layer in trapping upward diffusing $P$ is related to the concentration of dissolved iron in the anoxic hypolimnion. In Lake Lugano the two considered sites present major difference of iron concentration, and this difference is reflected in the $P$ sedimentation fluxes. The exposition of an additional sedimentation trap above the maximal oxycline height has allowed to gain insight into this phenomenon.
\end{abstract}

Key words: Lake Lugano, sediment trap, vertical phosphorus enrichment, iron redox boundary

\section{INTRODUCTION}

Under ideal climatic and radiant conditions algal growth in the euphotic zone of a lake is often limited by the concentration and the proper balance of nutrients. In many eutrophic lakes, phosphorus is considered the limiting substrate. Although its availability restricts growth rates, overall primary production can still remain high even under conditions when the concentration of phosphorus in the epilimnion is minimal (which is usually the case during summer stratification). This is due to the rapid endogenic cycling of phosphorus (Schwedt 1996). Phosphate-P can be assimilated during photosynthesis and is released again within a few days. Moreover, $1 \mathrm{~kg}$ of $\mathrm{P}$ is enough to produce $114 \mathrm{~kg}$ of algal dry mass, containing $41 \mathrm{~kg}$ of carbon and $7.2 \mathrm{~kg}$ of nitrogen, according to Redfield's stoichiometry (Redfield et al. 1963). These considerations illustrate that small $\mathrm{P}$ concentrations cycled rapidly can lead to photosynthetic scavenging of large amounts of $\mathrm{C}$ and $\mathrm{N}$.

$\mathrm{P}$ is removed from the epilimnion in various forms through the outflow and by seston sedimentation. While outflow is an irreversible loss of $\mathrm{P}$, sedimentation maintains $\mathrm{P}$ in the lake for internal cycling. Microbial degradation of detritus during sedimentation and during sediment diagenesis releases phosphate which can be cycled several times and through different phases. Settling particulate $\mathrm{P}$ (PP) is composed of organicallybound and mineral forms of phosphate, of amorphous precipitation products or of dissolved P (DP) which has adsorbed to particles (Holtan et al. 1988). During sedimentation, PP together with redox sensitive nutrients (carbon and nitrogen), undergo physical (Paerl 1973) and biogeochemical transformations (Gächter \& Bloesch 1985; Gächter \& Mares 1985; Bernasconi et al. 1997).

Here we report results of a sedimentation study, performed in the southern basin of the seasonally anoxic Lake Lugano, Switzerland, during 1996 and 1998. Sediment traps were exposed at two separated locations of the lake at three different depths. These sites are representative for the two sub-basins composing the southern part of Lake Lugano and their watersheds are very different from a geological point of view. The project is aimed at understanding the importance of sediment chemistry on P-cycling and bioavailability in the water column, by taking into account lateral heterogeneity within the lake. The recognition of heterogeneity is important for making reliable forecasting of the trophic evolution of a eutrophic water body, in response to its capacity to rescavenge the $\mathrm{P}$ released from sediments.

\section{SAMPLING SITES AND METHODS}

Lake Lugano is a deep, dendritic subalpine lake located at the Swiss-Italian border. The present work concentrates on its monomictic southern basin, in particular on the sites of Melide and Figino (Fig. 1), which are monitored monthly in the framework of the International Commission for the Protection of Italian-Swiss 
Waters. The major inflows for the southern basin are the northern basin and the Vedeggio River. Lake water flows from East to West and the outlet, the Tresa River, is located in a third smaller basin. Table 1 reports Lake Lugano's (southern basin) main hydrographic characteristics (LSA 1998).

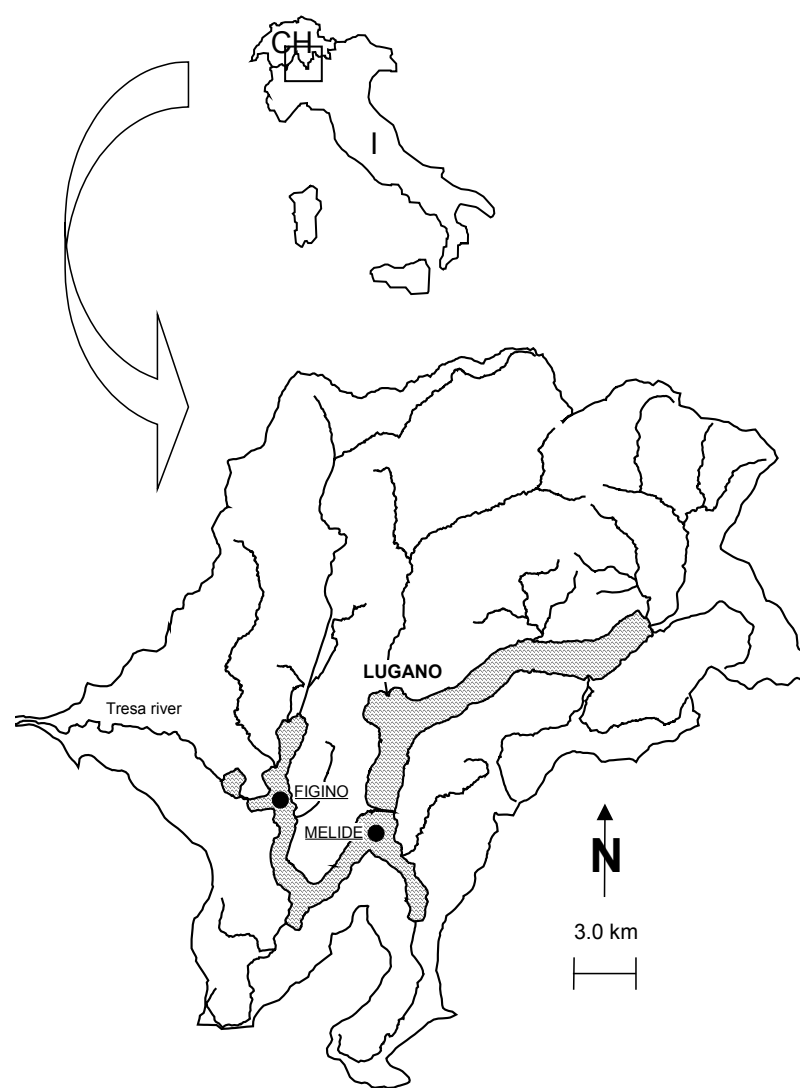

Fig. 1. Map of Lake Lugano with indication of main sampling stations.

Tab. 1. Main hydrographic characteristics (1995) of the southern basin of Lake Lugano (from LSA 1998).

\begin{tabular}{lcc}
\hline Catchment surface & $\mathrm{km}^{2}$ & 607.8 \\
Lake surface & $\mathrm{km}^{2}$ & 20.3 \\
Maximum depth & $\mathrm{m}$ & 95 \\
Average depth & $\mathrm{m}$ & 56 \\
Volume & $\mathrm{km}^{3}$ & 1.14 \\
Output volume & $\mathrm{km}^{3} \mathrm{y}^{-1}$ & 0.77 \\
Residence time & $\mathrm{y}$ & 1.48 \\
\hline
\end{tabular}

Lake Lugano is affected by eutrophication since the fifties, due to input of untreated sewage, rich in $\mathrm{P}$ and organic matter from urban settlements. Since the construction of the first waste disposal and sewage plants in the seventies, the $\mathrm{P}$ loading has been progressively reduced and the lake is slowly becoming less eutrophic. In spite of these important external recovery measures, Lake Lugano is considered still highly eutrophic. Actually, total $\mathrm{P}$ concentration at winter overturn still amounts to $80 \mu \mathrm{g} \mathrm{l}^{-1}$ and primary production remains about $340 \mathrm{~g} \mathrm{C} \mathrm{m}^{-2} \mathrm{y}^{-1}$ (LSA 1996a, b, 1998). During summer-autumn stratification anoxia develops from the sediment moving in the hypolimnion to approximately $60 \mathrm{~m}$ depth. Considerable concentrations of $\mathrm{NH}_{4}^{+}, \mathrm{Mn}^{2+}$, $\mathrm{Fe}^{2+}, \mathrm{CH}_{4}$ and DP are observed within this anoxic layer. For a more detailed description of the lake's annual cycle we refer to Barbieri \& Mosello (1992), Lazzaretti \& Hanselmann (1992) and Barbieri \& Simona (2001).

To collect settling material, Plexiglass cylinders (diameter: $10 \mathrm{~cm}$; height: $78 \mathrm{~cm}$ ) are employed. An aspect ratio $>5: 1$ and a diameter $>5 \mathrm{~cm}$ ensure optimal particle trapping efficiency (Bloesch \& Burns 1980). Additions of preservatives or antibiotics was not necessary because the traps were exposed for only two week periods between sampling. Between February 1996 and February 1998, three twin sediment traps were exposed near the deepest point at stations Melide and Figino at $20 \mathrm{~m}$, $60 \mathrm{~m}$ depth and $+6 \mathrm{~m}$ above the bottom (Fig. 2) in the centre of the basins (deepest point). The bottom trap $(+6$ m) corresponds to $79 \mathrm{~m}$ and $88 \mathrm{~m}$ depth at Melide and Figino, respectively. For a better comparison between the two locations, from May 1997 a fourth trap was exposed at Figino at $79 \mathrm{~m}$, which corresponds to the depth of the lowest trap at Melide. From previous studies it is known that sediment traps have to be exposed at more than three meters above the sediment to prevent overcatching (Bloesch \& Burns 1980; Bloesch 1995). Twenty meters depth trap collects particulate matter (PM) sedimenting from the epilimnion, whereas $60 \mathrm{~m}$ correspond to the average topmost depth of the anoxycline.

After trap retrieval the settled material is kept in the dark at $5{ }^{\circ} \mathrm{C}$ and analysed within one day. Measured parameters are PM, Total Carbon (TC), Particulate Organic Carbon (POC), Particulate Nitrogen (PN) and Particulate Phosphorus (PP). PM is weighted after oven drying $\left(60{ }^{\circ} \mathrm{C}\right.$ for 4 days). For TC detection subsamples are filtered through Whatman $\mathrm{GF} / \mathrm{C}$ glass-fibre filters precombusted at $950{ }^{\circ} \mathrm{C}$ for 24 hours to remove carbon. After filtration, filters are folded and introduced in tin capsules, dried at $60{ }^{\circ} \mathrm{C}$ for four days. TC is then measured with a Carlo Erba NA 1500 elemental analyser. The POC content is measured as that portion of the TC which remains after acidification $\left(\mathrm{H}_{2} \mathrm{SO}_{4} 3 \%\right)$ of the samples and washing with deionized water directly on the precombusted $\mathrm{GF} / \mathrm{C}$ filter to eliminate carbonate carbon. Particulate Inorganic Carbon (PIC) is calculated as the difference between TC and POC. For PN analysis a subsample is digested in the autoclave $\left(120^{\circ} \mathrm{C}\right.$ for one hour) in presence of a mineralization solution according to Valderrama (1981). The digest is filtered through a $\mathrm{GF} / \mathrm{C}$ filter and $\mathrm{N}$ is determined in the filtrate as $\mathrm{NO}_{3}{ }^{-}$ by UV spectrophotometry at $210 \mathrm{~nm}$. After digestion with $\mathrm{K}_{2} \mathrm{~S}_{2} \mathrm{O}_{8}(5 \%)$ at $120{ }^{\circ} \mathrm{C}$ for 1 hour and filtration, $\mathrm{P}$ is determined colorimetrically by continuos flow analysis (TRAACS, Bran \& Luebbe) according to Vogler (1965). 


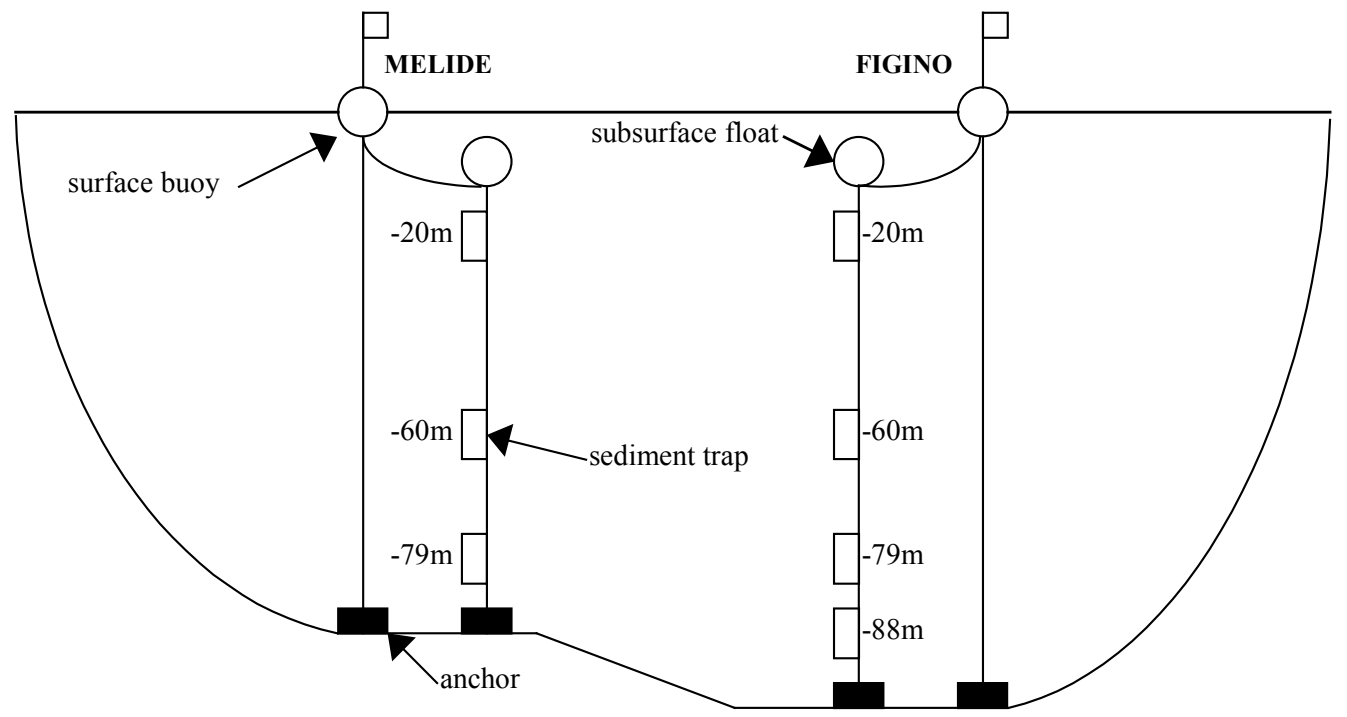

Fig. 2. Facility for sediment trap exposure. Starting from the end of May 1997 a fourth trap is exposed at Figino at $79 \mathrm{~m}$ depth.

Tab. 2. Cumulated sedimentation fluxes measured at Melide and Figino stations during two limnological years (i.e. between winter mixing), expressed in $\mathrm{g} \mathrm{m}^{-2} \mathrm{y}^{-1}$. Three traps were positioned at $-20 \mathrm{~m},-60 \mathrm{~m}$ and $+6 \mathrm{~m}$ above ground. POC $=$ particulate organic matter; PIC $=$ particulate inorganic carbon; $\mathrm{PP}=$ particulate phosphorus; $\mathrm{PM}=$ particulate matter. * since 21.5.97.

\begin{tabular}{|c|c|c|c|c|c|c|c|c|c|c|c|}
\hline \multirow[b]{2}{*}{ Station } & \multirow[b]{2}{*}{ depth (m) } & \multicolumn{5}{|c|}{$1996(20.2 .96 \rightarrow 18.2 .97)$} & \multicolumn{5}{|c|}{$1997(18.2 .97 \rightarrow 24.2 .98)$} \\
\hline & & PM & POC & PIC & $\mathrm{PN}$ & PP & PM & POC & PIC & $\mathrm{PN}$ & PP \\
\hline Melide & 20 & 847 & 74 & 49 & 10.0 & 1.8 & 641 & 68 & 29 & 9.4 & 1.5 \\
\hline Melide & 60 & 773 & 78 & 37 & 9.5 & 2.3 & 570 & 67 & 12 & 9.9 & 1.9 \\
\hline Melide & 79 & 786 & 87 & 35 & 10.5 & 3.0 & 600 & 75 & 17 & 10.4 & 2.3 \\
\hline Figino & 20 & 761 & 85 & 33 & 10.4 & 2.1 & 909 & 89 & 27 & 11.5 & 2.3 \\
\hline Figino & 60 & 686 & 86 & 25 & 10.3 & 2.9 & 1022 & 92 & 15 & 11.6 & 3.1 \\
\hline Figino & $79 *$ & - & - & - & - & - & 725 & 77 & 14 & 10.3 & 3.1 \\
\hline Figino & 88 & 754 & 99 & 21 & 11.8 & 4.9 & 949 & 104 & 11 & 13.9 & 5.3 \\
\hline
\end{tabular}

\section{RESULTS}

\subsection{Horizontal flux differences}

Table 2 summarises the annual fluxes measured at both stations in 1996 and 1997. Important flux variations are evident on an interannual basis both on the vertical and horizontal (between Melide and Figino) dimension. In 1996 sedimentation fluxes at Melide are on the average $24 \%$ higher than in the following year, with the exception of the PN flux at $60 \mathrm{~m}(-4.2 \%)$. In 1997 at Figino PM, POC, PN and PP fluxes show an average increase in the order of $+15 \%$, whereas PIC fluxes are about 35\% lower than in 1996. It emerges that values measured at Figino are generally higher than those measured at Melide, i.e. they increase along the water flow axis across the lake, except for PIC $(-54 \%$ in 1996 and $-14 \%$ in 1997) and for PM (-9\% in 1996). For the other parameters measured in 1996 this horizontal sedimentation difference amounts to $+12 \%$ for POC, $+8 \%$ for PN and $+25 \%$ for PP. These values are lower than in 1997, when they reach $+37 \%$ (PM), $+26 \%$ (POC), $+19 \%(\mathrm{PN})$ and $+43 \%(\mathrm{PP})$.
In the biennium 1996-1997 sedimentation fluxes show relevant seasonal variations (e.g. POC and PP as shown in figures 3 and 5), which are related to autochthonous productivity changes (mainly photosynthesis and calcite precipitation) and to allochthonous inputs due to meteorological events. Fluxes are maximal in spring and summer and minimal in autumn and during winter overturn, for all parameters (except for P) and at all depths.

\subsection{Vertical flux differences}

The highest PM-fluxes are measured during spring and summer. In particular in June 1997 at Figino (-20 m) a sedimentation flux of $14,400 \mathrm{mg} \mathrm{m}^{-2} \mathrm{~d}^{-1}$ was recorded after strong rainfall events $(300 \mathrm{~mm}$ in two weeks), in consequence of an input of particulate matter through tributaries. Fluxes are minimal in autumn and winter (on the average $500 \mathrm{mg} \mathrm{m}^{-2} \mathrm{~d}^{-1}$ ). During the exposure time PM fluxes usually decrease by $10 \%$ between $-20 \mathrm{~m}$ and $-60 \mathrm{~m}$ and they increase again towards the bottom. 
POC sedimentation peaks (Fig. 3) coincide with algal blooms: Diatoms in winter and spring, Chlorophytes and Cyanophytes in summer and autumn (LSA 1998), reaching $800 \mathrm{mg} \mathrm{m}^{-2} \mathrm{~d}^{-1}$ (Figino, April 1996). POC peaks are usually followed by periods with low fluxes corresponding to low primary production periods or to clear water phases caused by high zooplankton grazing activity (e.g. at the end of May 1997) characterised by high Secchi disk transparency (up to $8 \mathrm{~m}$; LSA 1998). POC fluxes are also affected by external phenomena, as it happened as a consequence of the rainy June 1997, when large amounts of terrestrial organic matter were transported into the lake through the tributaries.
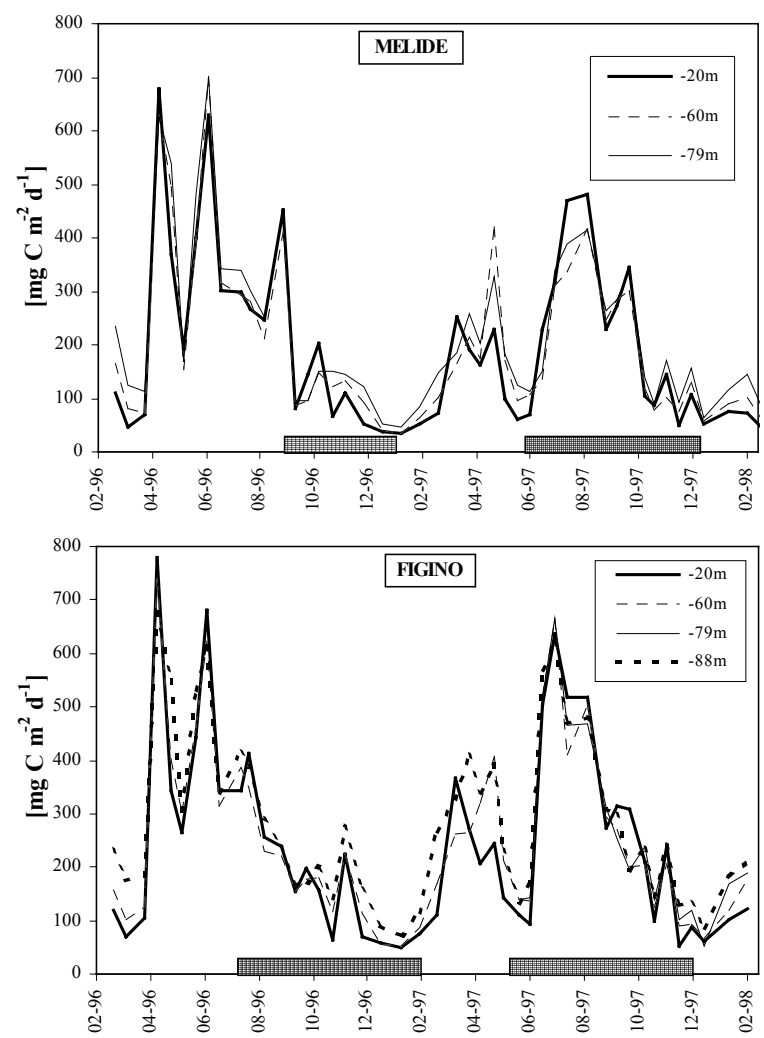

Fig. 3. Annual variations of particulate organic carbon (POC) sedimentation fluxes at different depths. Bars at the bottom of each figure indicate anoxic phase in the hypolimnion.

Figure 4 reports the annual trend of primary production and POC sedimentation fluxes at $20 \mathrm{~m}$ (both expressed as $\mathrm{mg} \mathrm{C} \mathrm{m} \mathrm{m}^{-2}$ ), as well as the mean POC concentration within the $0-20 \mathrm{~m}$ water column (from LSA 1997). The seasonal dynamic of the three parameters is similar at both stations, suggesting that the organic matter collected in the $20 \mathrm{~m}$ sediment trap is mainly of autochthonous origin. Comparing primary production and POC fluxes, it emerges that $75-80 \%$ of the fresh biomass is probably grazed by zooplankton or mineralised within the epilimnion. The effect of this bacterial metabolic activity is evident mainly in autumn, when a dramatic decrease in oxygen concentration $(<2$ $\mathrm{mg} \mathrm{l}^{-1}$ ) at about 15-20 $\mathrm{m}$ depth is observed (LSA 1998). On the vertical profile POC content in the settling matter increases constantly at both sites towards the bottom showing a mean accumulation of about $+15 \%$, between $-20 \mathrm{~m}$ and the bottom trap.

PN fluxes also present a similar increase with depth which is, however, about 10 times smaller than POC fluxes. The calculated PN/POC mass ratio is $0.12 \pm 0.01$ and the significant correlation of $r^{2}=0.75$ indicates that $\mathrm{N}$ is present mainly in organically bound form. The highest PN sedimentation fluxes are measured in June 1996 at Figino at $79 \mathrm{~m}$ depth $\left(100 \mathrm{mg} \mathrm{m}^{-2} \mathrm{~d}^{-1}\right)$.
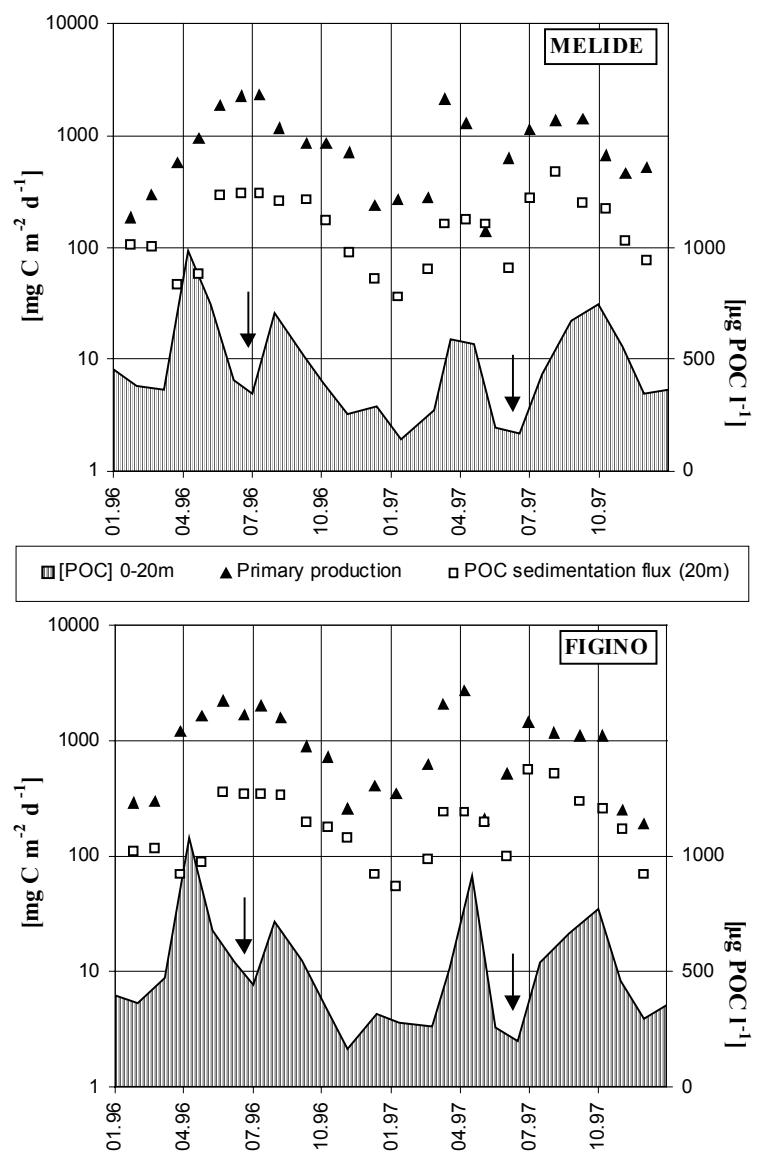

Fig. 4. Seasonal evolution of primary production, POC sedimentation flux and POC concentration in the $0-20 \mathrm{~m}$ layer, during the biennium 1996-1997. The arrows indicate the clear water phase, following the high grazing activity of herbivorous zooplankton.

PIC fluxes show a different trend compared to POC and PN. They are composed essentially of endogenical calcite $\left(\mathrm{CaCO}_{3}\right)$, formed under conditions of active photosynthesis in the epilimnion. $\mathrm{CaCO}_{3}$ precipitates are detectable in large quantities in the $20 \mathrm{~m}$ trap. PIC fluxes decrease during settling by 30 to $40 \%$ in the lower traps owing to $\mathrm{CaCO}_{3}$ dissolution (lowering as a consequence of biomass mineralisation and consequent $\mathrm{CO}_{2}$ production). In 1996 the first $\mathrm{CaCO}_{3}$ precipitation 
was recorded in April, whereas in 1997 it occurred later in July.

PP sedimentation dynamic is quite similar to POC and PN, although the largest discrepancies between the three traps are observed for this parameter. Actually, summer and autumnal PP fluxes increase massively towards the bottom, with different intensities between the sampled stations (Fig. 5). In Melide this accumulation is constant and amounts on the average to $+63 \%$ from -20 $\mathrm{m}$ to $-79 \mathrm{~m}$, whereas in Figino a first increase of $+28 \%$ is observed between the $-20 \mathrm{~m}$ and $-60 \mathrm{~m}$ trap, followed by a further major augmentation of $95 \%$ taking place from $-60 \mathrm{~m}$ to $-88 \mathrm{~m}$. Considering the whole water column, in Figino a net PP flux increase of $+133 \%$ from the surface to the bottom is observed. The highest fortnightly PP accumulation flux is recorded at Figino at the end of November 1997 with a net $1200 \%$ increase.
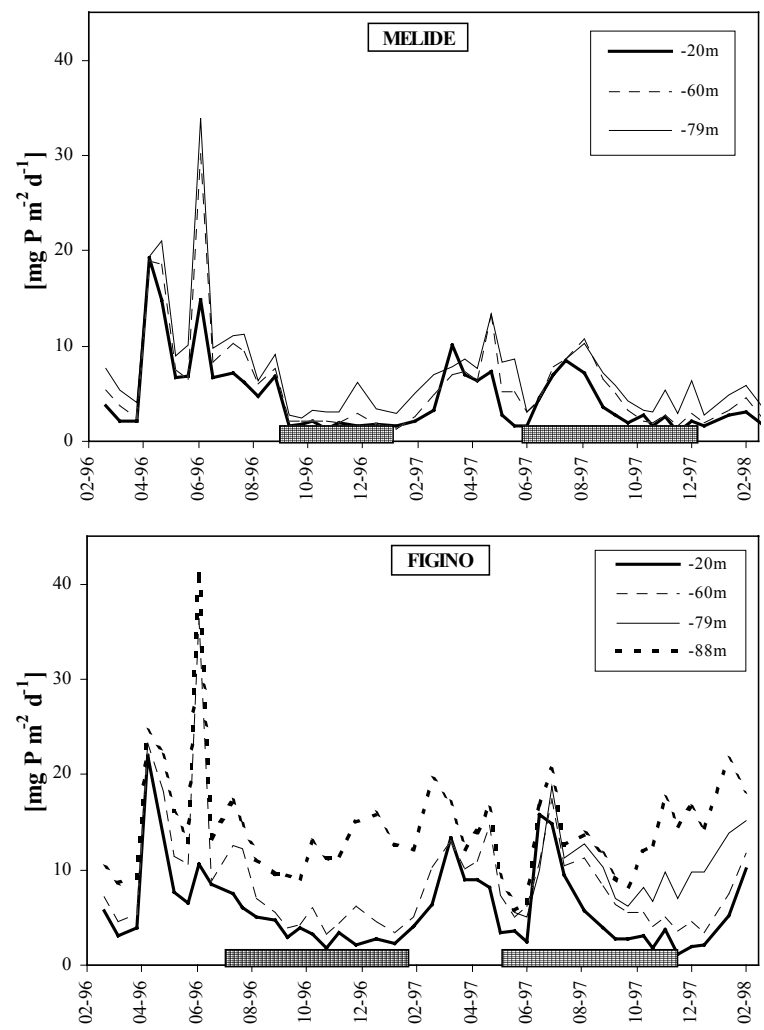

Fig. 5. Annual variations of particulate phosphorus (PP) sedimentation fluxes at different depths. Bars at the bottom of each figure indicate anoxic phase in the hypolimnion.

\section{DISCUSSION}

Sediment traps are the main tools for quantitative sedimentation studies and are usually exposed only at the site of maximal depth of a basin. In general, results are then considered representative for the whole lake. Apart from the case of eutrophic and hypereutrophic lakes, this is a questionable operation since it does not take into account biogeochemical and hydromorphological differences within the lake, which can be very marked in eutrophic and hypereutrophic lakes. Furthermore, collectors of settling material are normally exposed just below the epilimnion and a few metres above sediment, without considering transformation and accumulation processes taking place e.g. at oxycline depth. Sediment resuspension (secondary flux) is a phenomenon which deserves particular attention, since it can artificially increase sedimentation fluxes near the bottom (Bloesch 1995).

\subsection{Sedimentation fluxes}

From the sedimentation data it becomes clear that $\mathrm{P}$ is involved in additional biogeochemical processes compared to $\mathrm{C}$ and $\mathrm{N}$. The fact that yearly fluxes of PM, POC and PN always show an increasing trend between $-60 \mathrm{~m}$ and the $+6 \mathrm{~m}$ trap, indicates that it cannot be resuspension, which would transport only occasionally sediment matter to the trap exposed at $+6 \mathrm{~m}$ from the bottom. Benthic currents measured in the southern basin are in the order of $2-3 \mathrm{~cm} \mathrm{~s}^{-1}$ (Salvadè, pers. comm.), which is not enough to resuspend even light organic particles (Bloesch 1995; Gloor et al. 1994). However, during winter overturn stronger currents $\left(>6 \mathrm{~cm} \mathrm{~s}^{-1}\right)$ have been registered, which theoretically could resuspend large $(\varnothing>100 \mu \mathrm{m})$ organic particles. But POC fluxes in settling matter remain low and there is no POC content difference between the three traps during winter mixing. For this reason sediment resuspension could be excluded. To a similar conclusion came Bernasconi et al. (1997) analysing $\mathrm{C}$ and $\mathrm{N}$ isotopes in settling material. These authors suggest that lateral transport and focusing processes prevail over resuspension.

At winter overturn, in the whole water column, filamentous brown aggregates covering suspended matter are observed. These forms resemble Leptothrix-like chains, which are known to gain energy from $\mathrm{Fe}^{2+}$ oxidation and probably also from $\mathrm{Mn}^{2+}$ (Lampert \& Sommer 1993). Bacteria with similar metabolism have been described in other eutrophic Swiss lakes (Metallogenium, Hupfer et al. 1995). This suggests that during lake mixing $\mathrm{Mn}^{2+}$ dissolved in the anoxic hypolimnion is transported upwards and precipitates on contact with oxygen at the oxycline, covering the settling matter. In fact, particulate $\mathrm{Mn}$ has been observed only during overturn and in the following two months (LSA 1994, unpublished data).

The fact that POC and PN fluxes at Figino are higher (up to $30 \%$ ) than at Melide can be interpreted on one hand with the larger supply of particulate organic matter transported to Figino from the SE-arm of the lake (Capolago-Morcote) and from the Gulf of Agno, and on the other hand with the higher primary production of Figino. Between 1993 and 1997 the average primary production is $317 \pm 37 \mathrm{~g} \mathrm{C} \mathrm{m}^{-2} \mathrm{y}^{-1}$ in Melide and $356 \pm 34$ $\mathrm{g} \mathrm{C} \mathrm{m}^{-2} \mathrm{y}^{-1}$ in Figino (LSA 1996a, b; 1998).

Stoichiometric POC/PP ratios exceed the "ideal" Redfield value of 106 (Redfield et al. 1963) only during 
stagnation at all depths in Melide and in the upper trap of Figino, indicating that $\mathrm{P}$ becomes limiting for algal growth (Gächter \& Bloesch 1985; Uehlinger \& Bloesch 1987). POC/PP ratios generally decrease with depth, due to continuos $\mathrm{P}$ enrichment during sedimentation rather than to mineralisation of organic matter (in fact POC fluxes increase towards bottom as shown in figure 3). This might be explained as a $P$ transfer from settling seston (as particulate $\mathrm{P}$ ) and from the surrounding water (as DP), to heterotrophic organisms colonising sedimenting matter, within a tightly coupled microbial loop. In the deepest trap molar POC/PP ratios approach 50 which is similar to values found in aquatic bacteria (Fenchel \& Blackburn 1979; Rheinheimer et al. 1988).

Comparing sedimentation fluxes of Lake Lugano with another eutrophic Swiss lake, Lake Sempach (Hupfer et al. 1995), it emerges that values are in the same order of magnitude as far as $\mathrm{P}$ is concerned. With respect to POC and PN, fluxes are $20-30 \%$ greater in Lake Lugano.

\subsection{PP enrichment during sedimentation}

There are several possibilities to explain the vertical increase of PP sedimentation fluxes. DP may be assimilated by heterotrophic and autotrophic bacteria colonising suspended biomass. Abiotic adsorption to particle surfaces, coprecipitation (Holtan et al. 1988; Gächter \& Mares 1985) or to particle aggregation (Paerl 1973) are also likely to take place. In the southern basin calcite precipitation in the epilimnion and its following re-dissolution in the hypolimnion may actively transport P form surface to deep layers (Tab. 2). However, this process seems to be negligible, since the major calcite loss is observed between the first and the second trap, when only a slight PP increase is measured. Furthermore, the ratio between PP and PIC fluxes is not constant (increases with depth), indicating that other phenomena prevail in controlling $\mathrm{P}$ accumulation in the hypolimnion.

At Figino sedimentary PP fluxes are higher than at Melide at all depths (Tab. 2). This is probably due to horizontal transport, as it is the case for POC. In fact, all the water leaving Lake Lugano flows via the Figino sub-basin, which act as a decantation basin. In 1996 mean PP-flux increase between $-20 \mathrm{~m}$ and $-60 \mathrm{~m}$ amounts to $1.44 \mathrm{mg} \mathrm{P} \mathrm{m}^{-2} \mathrm{~d}^{-1}$ at Melide and to $2.09 \mathrm{mg}$ $\mathrm{P} \mathrm{m}^{-2} \mathrm{~d}^{-1}$ at Figino (Fig. 6), resulting rather regular during the year. On the contrary, important seasonal and spatial variations in the flux difference occur between $60 \mathrm{~m}$ and bottom traps. While at Melide PP enrichment between $-60 \mathrm{~m}$ and $-79 \mathrm{~m}$ does not show marked fluctuations during the year with an average value of $1.41 \mathrm{mg} P$ $\mathrm{m}^{-2} \mathrm{~d}^{-1}$, at Figino the increase between $-60 \mathrm{~m}$ and $-88 \mathrm{~m}$ is always larger but constant only between March and August (3.69 $\mathrm{mg} \mathrm{P} \mathrm{m}^{-2} \mathrm{~d}^{-1}$ ). Thereafter, the accumulation increases progressively until it reaches $11.23 \mathrm{mg} P$ $\mathrm{m}^{-2} \mathrm{~d}^{-1}$ in December 1996. By the end of March 1997, after winter overturn, enrichment fluxes reach their annual minimum at both sites.

In 1997 at Figino PP accumulation between $-60 \mathrm{~m}$ and $+6 \mathrm{~m}$ trap shows the same increase one month later than in 1996, reaching the maximum already in November (12.53 $\mathrm{mg} \mathrm{P} \mathrm{m}^{-2} \mathrm{~d}^{-1}$ ) and its minimum in March 1998 which coincides again with winter overturn. As for 1996, at Melide in 1997 the seasonal PP enrichment trend presents smaller fluctuations.

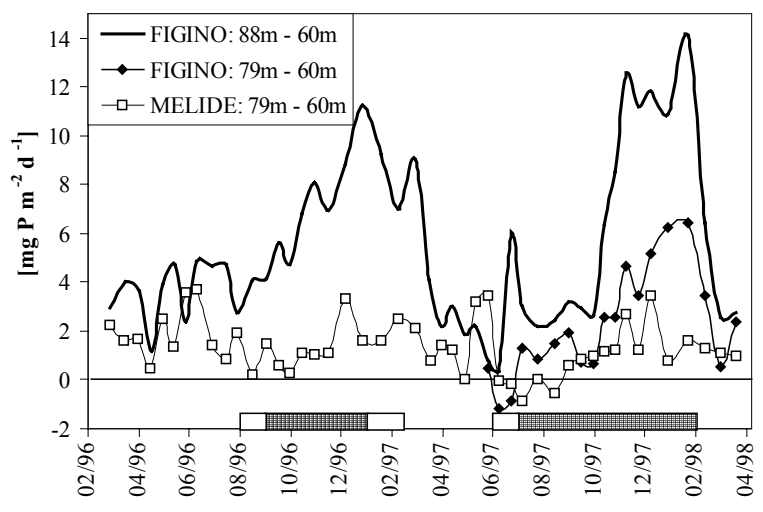

Fig. 6. Development of PP flux enrichment (1996-1998) during sedimentation, respectively from $60 \mathrm{~m}$ to $79 \mathrm{~m}$ and from $60 \mathrm{~m}$ to $88 \mathrm{~m}$ at Melide and Figino stations. The third series of data (- -) corresponds to PP augmentation between $60 \mathrm{~m}$ and $79 \mathrm{~m}$ at Figino. Bars at the bottom of the figure indicate anoxic phase. Given that anoxia at Figino is longer than at Melide, the white bars represent the difference between the two anoxic phases.

During the two-year period, POC accumulation with depth does not show similar patterns, neither at Melide nor at Figino (Fig. 6), confirming that $\mathrm{P}$ is subjected to additional physical and chemical transformations besides organic matter degradation and formation.

To explain $\mathrm{P}$ peculiar behaviour, the presence of two PP enrichment fluxes can be hypothesised, which overlap seasonally and whose effects are different at Figino and Melide. The first flux, here defined as PP progressive accumulation $\left(\mathrm{PP}_{\mathrm{acc}}\right)$, takes place at both sampling stations throughout the year at all depths without large variations. This primary flux is probably due to lateral transport followed by focusing of suspended matter and/or to the above mentioned enrichment processes. The secondary flux, called redox related PP accumulation $\left(\mathrm{PP}_{\mathrm{red}}\right)$, occurs mainly at Figino between September and winter overturn, and can be related to $\mathrm{P}$ inclusion into amorphous ferri-iron oxy/hydroxides formed at the oxycline. Actually, these particles (here defined as $\left.\mathrm{Fe}(\mathrm{OH})_{3(\mathrm{~s})}\right)$ show a large specific surface area (hundreds $\mathrm{m}^{2} \mathrm{~g}^{-1}$ ) to which DP can adsorb (Sulzberger et al. 1988; Stumm \& Morgan 1981), forming amorphous $\mathrm{Fe}(\mathrm{OH})_{3^{-}}$ $\mathrm{P}$ complexes. The complexity of Fe cycling at the redox boundary and its importance in controlling $\mathrm{P}$ has been stressed in many articles (e.g. Baccini 1985; Davison 1993; De Vitre et al. 1994). The present picture in- 
volves $\mathrm{Fe}^{2+}$ diffusing from the sediment into the anoxic hypolimnion where it precipitates again at the oxycline. The $\mathrm{Fe}(\mathrm{OH})_{3}$ colloids thus formed remain in suspension until they aggregate (Pizarro et al. 1995). On their journey to the bottom they scavenge DP (Belzile et al. 1996). A study performed on a seasonally anoxic lake by Davison et al. (1982) already provided evidence of increasing iron content in bottom sedimentation traps, due also to iron precipitation processes at the redox boundary. This transition zone is likely to act as a barrier preventing $\mathrm{P}$ from reaching the oxic hypolimnion and the epilimnion (Buffle et al. 1989). The settling $\mathrm{Fe}(\mathrm{OH})_{3}-\mathrm{P}$ particles collected in the sediment traps, account for the elevated P content. In 1994 an high resolution sampling campaign (LSA, unpublished data) took place in the hypolimnion of Figino, whose results showed that during stratification particulate iron (calculated as the difference between total and dissolved iron) increase was observed at the oxycline and often with evident peaks at the redox boundary.

$\mathrm{PP}_{\mathrm{acc}}$ and $\mathrm{PP}_{\text {red }}$ can be described by two simple equations (modified from Wehrli et al. 1995). $\mathrm{PP}_{\mathrm{acc}}$ flux is expressed as a function of particle (PM) flux and of $\mathrm{P}$ mean content in collected material between the $60 \mathrm{~m}$ and bottom sediment traps. Indexes II and III indicate respectively the second and the third sedimentation trap.

$$
\begin{gathered}
P P_{a c c}=\left(P M_{I I I}-P M_{I I}\right) * \frac{1}{2}\left(\frac{\left[P P_{I I I}\right]}{\left[P M_{I I I}\right]}+\frac{\left[P P_{I I}\right]}{\left[P M_{I I}\right]}\right) \\
P P_{r e d}=\left(P P_{I I I}-P P_{I I}\right)-P P_{a c c}
\end{gathered}
$$

The resulting trends of both enrichment phenomena are reported in figure 7. Applying equations 1 and 2 it has been assessed that overall PP increase in the deep hypolimnion (annual average) is due for $57 \%$ at Melide and $70 \%$ at Figino to $\mathrm{PP}_{\text {red. }}$. Highest $\mathrm{PP}_{\text {red }}$ fluxes occur at Figino in November and December when the anoxic layer is most pronounced (maximum peak in November 1997: $11.5 \mathrm{mg} \mathrm{P} \mathrm{m}^{-2} \mathrm{~d}^{-1}$ ). Episodic negative $\mathrm{PP}_{\text {acc }}$ values are due to fortnightly $\mathrm{PM}$ fluxes which are higher in sediment trap II than in III, whereas negative $\mathrm{PP}_{\text {red }}$ values are explainable as an overestimation of $\mathrm{PP}_{\mathrm{acc}}$.

The differences in sedimentation patterns between Figino and Melide (Fig. 5) are likely to be related to the water chemistry at the two sampling stations, which are influenced by the geological characteristic of the catchment area. Span et al. (1992) and Lazzaretti \& Hanselmann (1992) have shown that iron is a major discriminating factor for the characterisation of the $\mathrm{P}$ cycle in the sediments of Melide and Figino. The weathering of crystalline rock of the northern watershed conveys iron rich water to the Figino and Agno basins, whereas lake water flowing through the SE arm (transect CapolagoMelide-Morcote) is rich in carbonates from erosion of subalpine sedimentary nappes (Niessen 1987).
The averages of the highest yearly iron concentrations (period 1992-1995) are 340 and $183 \mu \mathrm{g} \mathrm{Fe}^{2+} \mathrm{l}^{-1}$, at Melide and Figino, respectively (LSA 1996a, b).
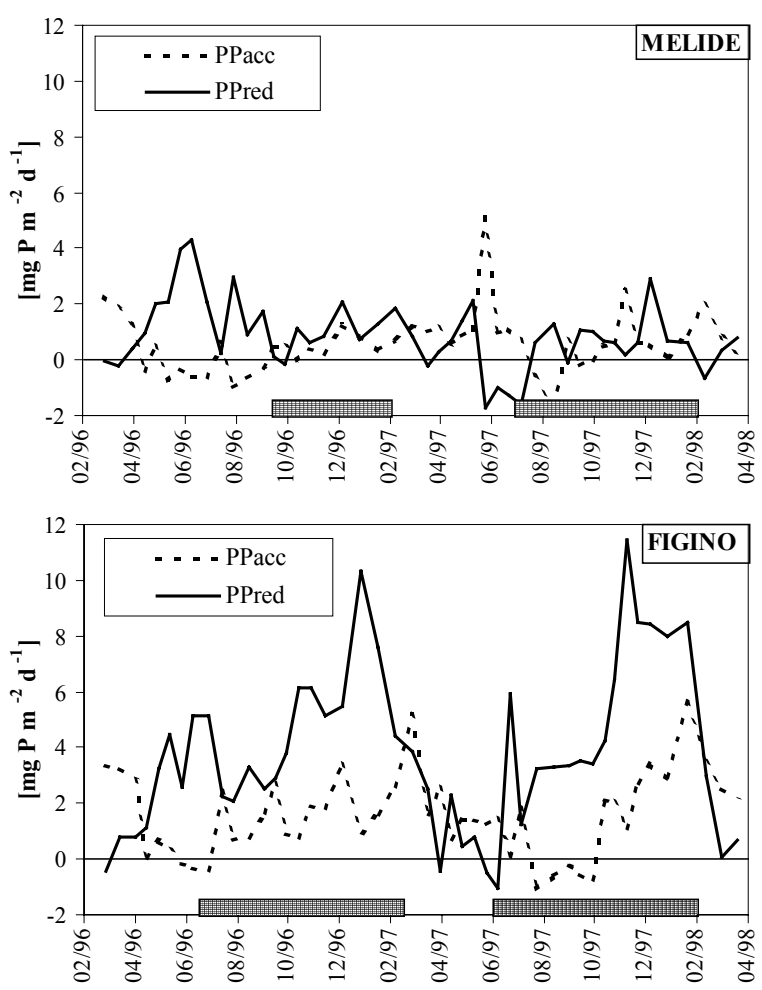

Fig. 7. Discrimination between the two processes responsible for PP flux enrichment during sedimentation from 60 to $79 \mathrm{~m}$, and from 60 to $88 \mathrm{~m}$ at Melide and Figino, respectively. The vertical accumulation $\left(\mathrm{P}_{\text {acc }}\right)$ takes place in the entire water column and is mainly due to lateral transport and to DP scavenging by settling matter. The second process, called redox driven $\mathrm{P}$ enrichment $\left(\mathrm{P}_{\mathrm{red}}\right)$, is related to the adsorption of DP to fresh precipitated ferri-iron oxy/hydroxides at the oxycline.

Coupling between iron and $\mathrm{P}$ cycles has also been studied during a recent campaign (LSA 1994, unpublished data). Within the anoxic layer of Figino a stoichiometric $\mathrm{PFe} / \mathrm{PP}(\mathrm{PFe}=$ particulate iron $)$ ratio of $2.26\left(r^{2}\right.$ $=0.8 ; \mathrm{n}=18)$ has been observed. Similar PFe/PP relationships have been measured for other lakes in sediment traps (Hupfer et al. 1995) and at the oxycline of lakes with a seasonally anoxic hypolimnion (citations in Buffle et al. 1989). In theory this unknown compound could be vivianite $\left(\left(\mathrm{Fe}_{3}\left(\mathrm{PO}_{4}\right)_{2} \times 8 \mathrm{H}_{2} \mathrm{O}\right)\right.$, although in other lakes vivianite was never observed in anoxic bottom waters, even though supersaturation was often reached (Jones \& Bowser 1978; Anderson \& Rippey 1988; Davison \& De Vitre 1992; Belzile et al. 1996). The observed molar $\mathrm{PFe} / \mathrm{PP}$ ratio could be characteristic of an amorphous $\mathrm{Fe}(\mathrm{OH})_{3}-\mathrm{P}$ complex formed at the Fe redox interface. Manganese is supposed not to be involved in the formation of particles in the anoxic hypolimnion, 
since it is found prevalently in dissolved form (LSA 1994, unpublished data).

\section{CONCLUSIONS}

Investigations of sedimentation fluxes in lakes should always consider spatial heterogeneity. Sedimentation processes are affected by chemical composition of the water where seston is suspended and by hydrological conditions. This study shows that there are two sedimentary $\mathrm{P}$ accumulation mechanisms in eutrophic lakes characterised by a seasonally anoxic hypolimnion (e.g. Lake Lugano, southern basin). The two processes occasionally overlap and their importance changes within the lake. The first one, here defined as standing accumulation, takes place during the whole year, at all depths. It is the net result of both DP uptake (biotic and abiotic) by settling seston and PP lateral transport of suspended matter. The second mechanism, the iron regulated $\mathrm{P}$ accumulation, can represent up to $70 \%$ of total PP enrichment and takes place mainly at sites with higher $\mathrm{Fe}$ at a redox boundary, where precipitation of $\mathrm{Fe}$ and $\mathrm{P}$ compounds plays a major role in controlling upward diffusion of DP from the bottom. Actually, the presence of $\mathrm{Fe}(\mathrm{OH})_{3}-\mathrm{P}$ precipitates can be hypothesised, which are formed at the oxycline and slowly sediment, preventing DP from reaching the epilimnion.

\section{ACKNOWLEDGMENTS}

We are very grateful to Dr. Stefano Bernasconi of the Department of Earth Sciences, Swiss Federal Institute of Technology (Zürich, Switzerland), for his critical reading of the paper. This study was funded by the Commissione internazionale per la Protezione delle Acque Italo-Svizzere (CIPAIS).

\section{REFERENCES}

Anderson, N.J. \& B. Rippey. 1988. Diagenesis of magnetic minerals in the recent sediments of a eutrophic lake. Limnol. Oceanogr., 33: 1476-1492.

Baccini, P. 1985. Phosphate interactions at the sediment-water interface. In: W. Stumm (Ed.), Chemical processes in lakes. Wiley Interscience, New York: 189-205.

Barbieri, A. \& R. Mosello. 1992. Chemistry and trophic evolution of Lake Lugano in relation to nutrient budget. Aquat. Sci., 54 (3/4): 219-237.

Barbieri, A. \& M. Simona. 2001. Trophic evolution of Lake Lugano related to external load reduction: Changes in phosphorus and nitrogen as well as oxygen balance and biological parameters. Lakes \& Reservoirs: Research and Management, 6: 37-47.

Belzile, N., J. Pizarro, M. Filella \& J. Buffle. 1996. Sediment diffusive fluxes of $\mathrm{Fe}, \mathrm{Mn}$, and $\mathrm{P}$ in a eutrophic lake: Contribution from lateral vs bottom sediments. Aquat. Sci., 58(4): 327-354.

Bernasconi, S., A. Barbieri \& M. Simona. 1997. Carbon and nitrogen isotope variations in sedimenting organic matter in Lake Lugano. Limnol. Oceanogr., 42(8): 1755-1765.

Bloesch, J. \& N.M. Burns. 1980. A critical review of sedimentation trap technique. Schweiz. Z. Hydrol., 42(1): 1555.
Bloesch, J. 1995. Mechanisms, measurement and importance of sediment resuspension in lakes. Mar. Freshwat. Res., 46: 295-304.

Buffle, J., R. De Vitre, D. Perret \& G. Leppard. 1989. Physico-chemical characteristics of a colloidal iron phosphate species formed at the oxic-anoxic interface of a eutrophic lake. Geochimica et Cosmochimica Acta, 53: 399-408.

Davison, W., C. Woof \& E. Rigg. 1982. The dynamics of iron and manganese in a seasonally anoxic lake; direct measurement of fluxes using sediment traps. Limnol. Oceanogr., 27(6): 987-1003.

Davison, W. \& R.R. De Vitre. 1992. Iron particles in freshwater. In: J. Buffle \& H.P. van Leeuven (Eds), Environmental particles. Lewis Publishers: 315-356.

Davison, W. 1993. Iron and manganese in lakes. EarthScience Reviews, 34: 119-163.

De Vitre, R., B. Sulzberger \& J. Buffle. 1994. Transformations of iron at redox boundaries. In: J. Buffle \& R. De Vitre (Eds), Chemical and biological regulation of aquatic systems. Lewis Publishers: 89-135.

Fenchel, T. \& T.H. Blackburn. 1979. Bacteria and mineral cycling. Academic Press, New York: 225 pp.

Gächter, R. \& A. Mares. 1985. Does settling seston release soluble reactive phosphorus in the hypolimnion of lakes? Limnol. Oceanogr., 30(2): 364-371.

Gächter, R. \& J. Bloesch. 1985. Seasonal and vertical variation in the C:P ratio of suspended and settling seston of lakes. Hydrobiologia, 128: 193-200.

Gloor, M., A. Wüest \& M. Münnich. 1994. Benthic boundary mixing and resuspension induced by internal seiches. Hydrobiologia, 284: 59-68.

Holtan, H., L. Kamp-Nielsen \& O. Stuanes. 1988. Phosphorus in soil, water and sediment: an overview. Hydrobiologia, 170: 19-34.

Hupfer, M., R. Gächter \& R. Giovanoli. 1995. Transformation of phosphorous species in settling seston and during early sediment diagenesis. Aquat. Sci., 57(4): 305-324.

Jones, B.F. \& C.J. Bowser. 1978. The mineralogy and related chemistry of lake sediments. In: A. Lerman (Ed.), Lakes: chemistry, geology, physics. Springer Verlag, New York: 179-235.

LSA-Laboratorio Studi Ambientali. 1996a. Ricerche sull'evoluzione del Lago di Lugano - aspetti limnologici. Campagne 1993 e 1994 (Programma quinquennale 19931997). Ed. Commissione Internazionale per la Protezione delle Acque Italo-Svizzere: $190 \mathrm{pp}$.

LSA-Laboratorio Studi Ambientali. 1996b. Ricerche sull'evoluzione del Lago di Lugano - aspetti limnologici. Campagna 1995 (Programma quinquennale 1993-1997). Ed. Commissione Internazionale per la Protezione delle Acque Italo-Svizzere: $100 \mathrm{pp}$.

LSA-Laboratorio Studi Ambientali. 1998. Ricerche sull'evoluzione del Lago di Lugano - aspetti limnologici. Campagne 1996 e 1997 e rapporto quinquiennale (Programma quinquennale 1993-1997). Ed. Commissione Internazionale per la Protezione delle Acque Italo-Svizzere: $124 \mathrm{pp}$.

Lampert, W. \& U. Sommer. 1993. Limnoökologie. Thieme Verlag, Stuttgart: $440 \mathrm{pp}$.

Lazzaretti, M.A. \& K.W. Hanselmann. 1992. The role of sediments in the phosphorus cycle in lake Lugano. II. Seasonal and spatial variability of microbiological processes at the sediment-water interface. Aquat. Sci., 54(3/4): 285299.

Niessen, F. 1987. Sedimentologische, geophysikalische und geochemische Untersuchungen zur Entstehung und Ablagerungsgeschichte des Luganersees (Schweiz). Diss. ETH Nr. 8354: 332 pp.

Paerl, H.W. 1973. Detritus in Lake Tahoe: Structural modification by attached microflora. Science, 180: 496-498. 
Pizarro, J., N. Belzile, M. Filella, G. Leppard, J.-C. Negre, D. Perret \& J. Buffle. 1995. Coagulation/sedimentation of submicron iron particles in a eutrophic lake. Wat. Res., 29(2): 617-632.

Redfield, A.C., B.H. Ketchum \& F.A. Richards. 1963. The influence of organisms on the composition of sea water. In: M.N. Hill (Ed.), The Sea. Wiley Interscience, New York: 26-77.

Schwedt, S. 1996. Taschenatlas der Umweltchemie. Thieme Verlag: $248 \mathrm{pp}$.

Rheinheimer, G., W. Hegemann, J. Raff \& I. Sekoulov. 1988. Stickstoffkreislauf im Wasser. Stickstoffumsetzung in natürlichen Gewässern, in der Abwasserreinigung und Wasserversorgung. Oldenburg Verlag, München: 394 pp.

Span, D., J. Dominik, M.A. Lazzaretti \& J.-P. Vernet. 1992. The role of sediments in the phosphorus cycle of lake Lugano. I. Geochemical approach. Aquat. Sci., 54(3/4): $277-284$.

Stumm, W. \& J. Morgan. 1981. Aquatic Chemistry. $2^{\text {nd }}$ ed. Wiley Interscience, New York: 800 pp.

Received: April 2002

Accepted: September 2002
Sulzberger, B., D. Suter, C. Siffert, S. Banwart \& W. Stumm. 1988. Wie wird im Eisenkreislauf der Gewässer das Eisenoxid aufgelöst? Mitteilungen der EAWAG, 26: 1-6.

Uehlinger, U. \& J. Bloesch. 1987. Variation in the C:P ratio of suspended and settling seston and its significance for $\mathrm{P}$ uptake calculations. Freshwat. Biol., 17: 99-108.

Valderrama, J.C. 1981. The simultaneous analysis of total nitrogen and total phosphorus in natural waters. Marine Chemistry, 10: 109-122.

Vogler, P. 1965. Beiträge zur Phosphoranalytik in der Limnologie; II. Die Bestimmung des gelösten Orthophosphates. Fortschr. Wasserchem. Grenzgeb., 2: 109-119.

Wehrli, B., G. Friedel \& A. Manceau. 1995. Reaction rates and products of manganese oxidation at the sedimentwater interface. In: C.P. Huang, C.R. O'Melia \& J.J. Morgan (Eds), Aquatic Chemistry: interfacial and interspecies processes. Washington, ACS, Advances in chemistry series, 244: 111-134. 